\title{
CURCUMIN PROTECTION AGAINST CADMIUM-INDUCED OXIDATIVE STRESS IN PANCREAS OF SWISS ALBINO MICE
}

\author{
SUMAN SHARMA, ANU* \\ Department of Zoology and Environmental Sciences, Punjabi University, Patiala - 147 002, Punjab, India. Email: anukalia686@gmail.com
} Received: 24 June 2018, Revised and Accepted: 07 September 2018

\begin{abstract}
Objective: This study was planned to explore the protective efficacy of Curcuma longa (curcumin) against cadmium chloride (CdCl ${ }_{2}$ )-induced oxidative stress in pancreatic tissue of albino mice.

Methods: A total of 40 albino mice were equally divided into eight groups (five mice for each). The mice were kept on standard feed and water ad libitum. Control Groups 1 and 5 mice were given equal amount of distilled water, Groups 2 and 6 mice received 1 mg/kg body weight of CdCl ${ }_{2}$ on alternate days, and Group 3 and 7 received $1 \mathrm{mg} / \mathrm{kg}$ body weight of $\mathrm{CdCl}_{2}$ on alternate days and $100 \mathrm{mg} / \mathrm{kg}$ body weight of curcumin every day. Groups 4 and 8 received $100 \mathrm{mg} / \mathrm{kg}$ body weight of curcumin daily and were kept as positive control. Autopsies were done on 15 and 45 days posttreatment. The pancreas was collected from each mouse and homogenized for biochemical study.
\end{abstract}

Results: The results of the present study revealed that Cd-induced oxidative stress depleted the antioxidant scavenger system and curcumin showed free radical scavenging potential. The activities of antioxidant enzymes, i.e., superoxide dismutase, catalase, glutathione peroxidase were observed to be significantly decreased, and methylenedioxyamphetamine concentration was increased in $\mathrm{CdCl}_{2}$-treated group which was restored to normal level after curcumin treatment.

Conclusion: It can be concluded that curcumin acts as a powerful and beneficial antioxidant against oxidative stress by scavenging the free radicals produced by $\mathrm{CdCl}_{2}$.

Keywords: Cadmium chloride, Curcumin, Oxidative stress, Glutathione peroxidase, Pancreas.

(C) 2018 The Authors. Published by Innovare Academic Sciences Pvt Ltd. This is an open access article under the CC BY license (http://creativecommons. org/licenses/by/4. 0/) DOI: http://dx.doi.org/10.22159/ajpcr.2018.v11i11.28700

\section{INTRODUCTION}

Heavy metals represent an environmental pollutant with toxicity to biota. Since the late $19^{\text {th }}$ century, heavy metals have accumulated in the environment by the mining and industrial waste. Cadmium (Cd) is one of the most toxic heavy metals ingested by animals and humans. The biological half-life of $\mathrm{Cd}$ is very long in animals [1]. Cd is largely used in Ni-Cd batteries, plastics manufacturing, and electroplating of steel. Cd is an extremely toxic heavy metal that can lead to acute and chronic Cd poisoning by accumulation in mammals, birds, and fishes through the food chain $[2,3]$. Cd has been reported to increase the impairment of pancreatic functions by causing structural deformation in the pancreatic $\alpha$ - and $\beta$-cells [4]. Cd also damages the liver, kidney, bones, nerves, and other organs [5,6]. Cd affects both endocrine and exocrine part of the pancreas, and its accumulation is reported even in those populations which are not directly exposed to $\mathrm{Cd}[7,8]$.

The various toxic effects induced by $\mathrm{Cd}$ in biological systems have been linked to increased lipid peroxidation and reduced antioxidant reserves of the body. Cd toxicity leads to enhanced lipid peroxidation and alterations in the antioxidant defense system which includes enzymes such as glutathione peroxidase (GPx), glutathione-S-transferase (GST), superoxide dismutase (SOD), catalase (CAT), and non-enzymatic molecule like glutathione, which normally protect against free radical toxicity [9]. Chopra et al. [10] also reported that Cd significantly enhanced lipid peroxidation and declined the levels of antioxidant, namely reduced glutathione, GST, SOD, and CAT activity.

The pancreas is more susceptible organ to oxidative stress than other tissues and organs because pancreatic islet cells show extremely weak manifestation of antioxidative enzymes [11]. Cd directly affects carbohydrate metabolism by injuring the islet of Langerhans and reducing the insulin secretion [12]. Cd in pancreas of rats is generally bound to metallothionein (MT). However, MT in pancreas is extremely susceptible to oxidative reactions as compared to MT in the liver, spleen, and kidneys [13]. Cd toxicity involves the reduction of glutathione and sulfhydryl groups, resulting in the enhanced production of various reactive oxygen species (ROS) such as superoxide ion, hydrogen peroxide, and hydroxyl radicals [14]. The levels of ROS are regulated by a variety of cellular defense mechanisms consisting of enzymic and non-enzymic antioxidants [15]. The primary scavenger enzymes involved in detoxification of ROS in mammalian systems are CAT, SOD, GPx, and GST [16]. Long exposure to Cd leads to necrosis, degeneration, and degranulation of $\beta$-cells, causing an increase in the serum glucose level and decrease in plasma insulin concentration causing alteration in blood and urine glucose level [17].

Curcumin [1,7-bis(4-hydroxy-3-methoxyphenyl)-1,6-heptadiene-3,5dione] is a yellow phenolic compound present in turmeric (Curcuma longa) a commonly used spice in Indian food. Curcumin has a significant antioxidant activity in both in vitro and in vivo studies [18-21]. Curcumin is also reported to have anticarcinogenic [22-24], anticataractogenic [25-27], anti-inflammatory [28], antidiabetic/ hypoglycemic [29], and antiglycating [30,31] activities. Curcumin also has a positive effect on blood glucose in diabetics and increases gastric mucosal secretion in rabbits [32]. Curcumin is a potent antioxidant agent and free radical scavenger [33]. It is also an inhibitor of lipid peroxidation [32] and also reduces the overexpression of nitric oxide synthase [34,35]. Similarly, Kalpana and Polasa [36,37] also reported that curcumin scavenges oxygen free radicals, inhibits lipid peroxidation, and protects cellular macromolecules including deoxyribonucleic acid from oxidative damage. 


\section{METHODS}

\section{Animals}

4-weak-old male Swiss albino mice weighing $20 \pm 2 \mathrm{~g}$ were used and purchased from the Central Research Institute, Kasauli (H.P). The animals were housed under standardized environmental conditions during experimental period. The pellet diet (obtained from Hindustan Liver Limited, Mumbai, India) and tap water were given ad libitum. All experiments were conducted in the Department of Zoology and Environmental Sciences, Punjabi University, Patiala, with the approval of the Institutional Animal Ethical Committee.

\section{Chemicals}

Cd chloride $\left(\mathrm{CdCl}_{2}\right)$ and curcumin powder were obtained from Hi-Media Laboratories Pvt., Ltd., Mumbai. Cd and curcumin were dissolved in distilled water and administered to mice orally. An aqueous suspension of curcumin was made according to Kamel et al. [38].

\section{Experimental design}

Mice were divided into following eight groups and five mice were kept in each group. Groups 1 and 5 were kept as control and tap water was given ad libitum. Groups 2 and 6 mice were administered $\mathrm{CdCl}_{2}$ orally at a dose of $1 \mathrm{mg} / \mathrm{kg}$ body weight on alternate days for 15 and 45 days. Groups 3 and 7 were given $1 \mathrm{mg} / \mathrm{kg}$ body weight of $\mathrm{CdCl}_{2}$ orally on alternate days and $100 \mathrm{mg} / \mathrm{kg}$ body weight of curcumin daily for 15 and 45 days, respectively. Groups 4 and 8 mice were administered orally $100 \mathrm{mg} / \mathrm{kg}$ body weight of curcumin daily for 15 and 45 days, respectively, and were kept as positive control. Autopsies were done on 15 and 45 days post-treatment.

\section{Biochemical analysis}

The pancreatic tissue was collected after autopsies from each group and washed with ice-cold saline to remove the blood. Tissue was minced and homogenized in $3 \mathrm{ml}$ of phosphate buffer $(\mathrm{pH}-7.2)$ and centrifuged $(\times 3000 \mathrm{~g}$ for $10 \mathrm{~min})$. The clear supernatant was used for various biochemical analyses.

\section{Measurement of oxidative stress markers}

Lipid peroxidation was measured by estimating the malondialdehydethiobarbituric acid reactive substances in pancreatic homogenate using the method [39].

\section{Estimation of antioxidant enzymes}

SOD was determined by the method [40]. CAT activity was assayed by the method [41]. GPx in pancreatic homogenate was quantified by the method of Ahrens [42].

\section{Statistical analysis}

The data were statistically analyzed by two-way analysis of variance followed by Student's t-test. The difference among means was analyzed by Tukey's t-test. The data reported in this study are considered statistically significant at ${ }^{*} \mathrm{p}<0.05$ levels.

\section{RESULTS}

Fig. 1 showed statistically significant $\left({ }^{*} \mathrm{p}<0.05\right)$ increase in methylenedioxyamphetamine (MDA) level in Groups 2 and $6\left(\mathrm{CdCl}_{2}\right)$ in comparison to control groups ( 1 and 5) at both the intervals, i.e. 15 and 45 days. Group $3(\mathrm{Cd}+\mathrm{Cur})$ showed statistically non-significant ( $>0.05)$ increase in MDA content and Group 7 (Cd + Cur) showed statistically significant $\left({ }^{*} \mathrm{p}<0.05\right)$ rise in MDA concentration as compared to control mice. The MDA content in antioxidant-treated Groups 4 and 8 (+ve Cur) showed statistically non-significant ( $p>0.05$ ) elevation in MDA content as comparison to control. The SOD activity showed a statistically significant $\left({ }^{*} \mathrm{p}<0.05\right)$ decline in Cd-treated mice (Groups 2 and 6) as compared to control Groups 1 and 5 (Fig. 2). Group 3 (Cd + Cur) showed statistically non-significant $(p>0.05)$ decrease in SOD value and Group 7 ( Cd + Cur) showed very statistically significant $\left({ }^{*} \mathrm{p}<0.05\right)$ reduction in SOD activity with respect to control group. The SOD activity in antioxidant supplemented Groups 4 and 8 (+ve Cur) showed statistically non-significant ( $p>0.05$ ) elevation in comparison to control value. Fig. 3 showed a statistically significant $\left({ }^{*} p<0.05\right)$ decrease in CAT activity in Cd-treated groups (2 and 6) in comparison to control Groups 1 and 5. Group $3(\mathrm{Cd}+\mathrm{Cur})$ showed statistically non-significant $(\mathrm{p}>0.05)$ decrease in CAT activity and Group 7 (Cd + Cur) showed very statistically significant $\left({ }^{*} \mathrm{p}<0.05\right)$ reduction in CAT activity with respect to control group. Groups 4 and 8 (+ve Cur) showed non-significant increase in CAT activity. Fig. 4 depicts that the Cd administration in Group 2 and 6 showed statistically non-significant ( $p>0.05)$ decrease and statistically significant decrease in the GPx activity, respectively, as compared to control at 15 and 45 days. A non-significant ( $>0.05)$ decrease was observed in Groups 3 and 7 with respect to control value. Groups 4 and 8 (+ve Cur) showed non-significant increase in GPx activity as compared to control mice.

\section{DISCUSSION}

Pancreatic cells are observed to be susceptible to oxidative damage because of the two reasons: One is their lower antioxidant defense machinery and other is the overproduction of ROS within the cell due to the exposure of the general population to the toxic substances in the daily life [43]. $\mathrm{Cd}$ is a toxic metal but is unable to generate ROS directly. However, Cd-induced oxidative stress is a common phenomenon observed in several studies [14]. It is already proved that oxidative stress plays an important role in Cd poisoning [44]. Cd exposure could trigger significant increase in blood glucose concentration and lipid peroxidation and significant decrease in body weight, blood insulin level, GSH, and activity of antioxidant enzymes in pancreatic tissue [45].

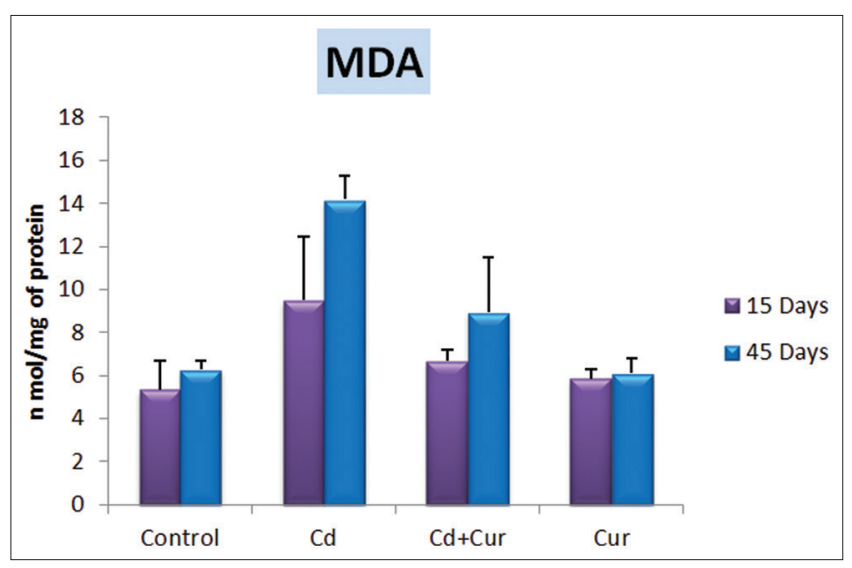

Fig. 1: Effect of curcumin on cadmium-induced changes in methylenedioxyamphetamine concentration in pancreatic tissue in the control and experimental mice. Values are given as mean \pm standard deviation from five mice in each group

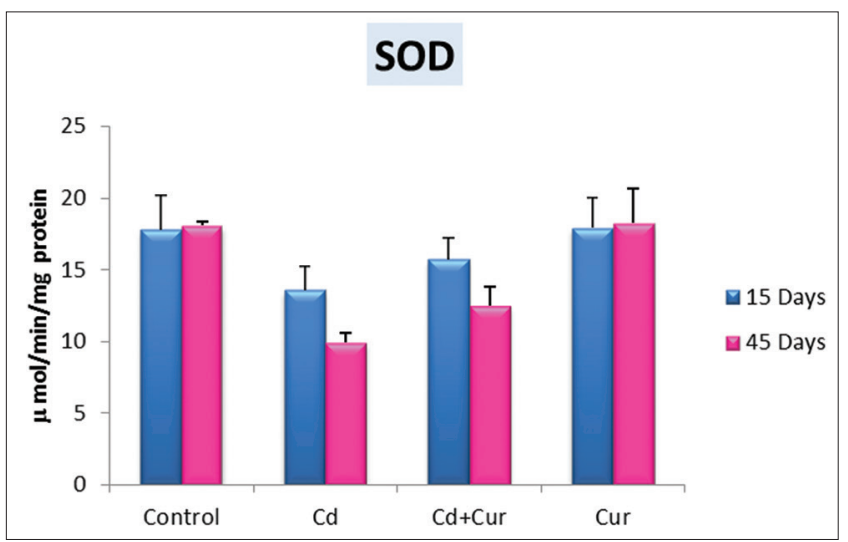

Fig. 2: Effect of curcumin on cadmium-induced changes in superoxide dismutase level in pancreatic tissue in the control and experimental mice. Values are given as mean \pm standard deviation from five mice in each group 


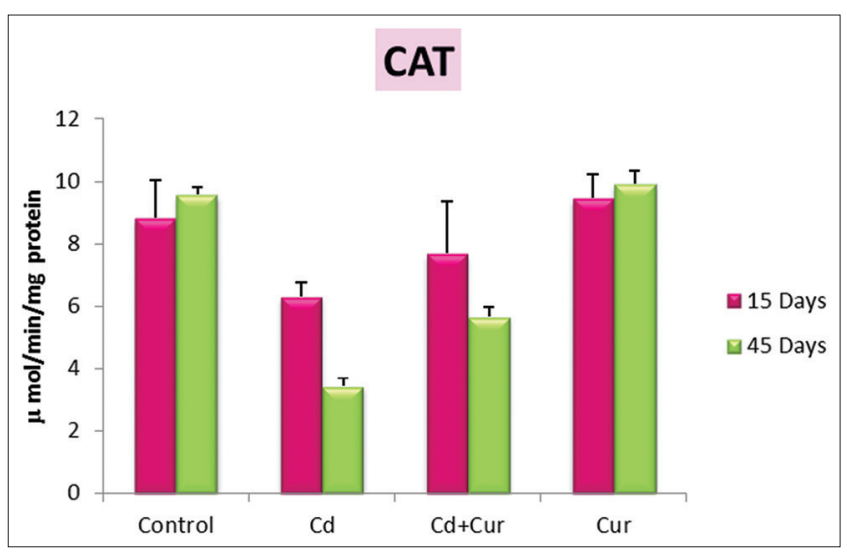

Fig. 3: Effect of curcumin on cadmium-induced changes in catalase level in pancreatic tissue in the control and experimental mice. Values are given as mean \pm standard deviation from five mice in each group

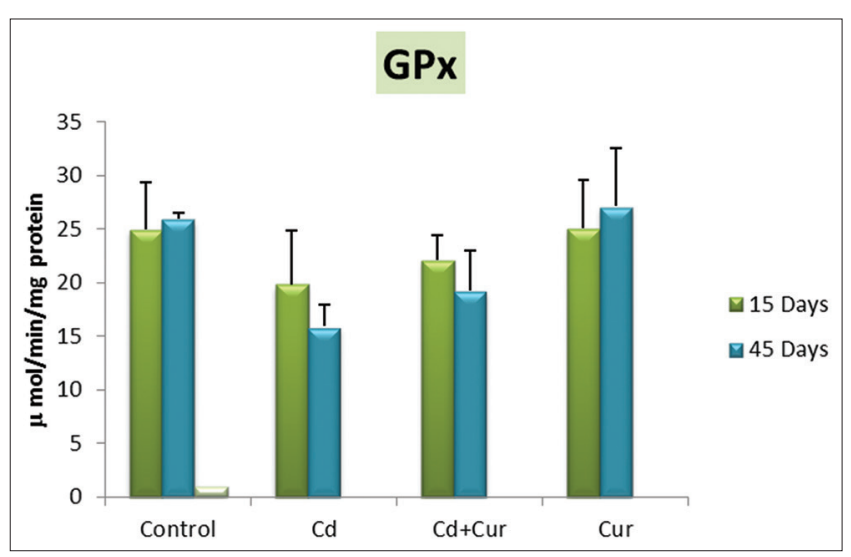

Fig. 4: Effect of curcumin on cadmium-induced changes in glutathione peroxidase level in pancreatic tissue in the control and experimental mice. Values are given as mean \pm standard deviation from five mice in each group

Liu [46] found that Cd concentration and MDA content were elevated and antioxidant activity markers (CAT, SOD, GSH-Px, and T-AOC) were decreased in pancreas of chickens exposed to Cd. Similarly, Cd treatment elevated the MDA concentration and decreased levels of GSH, SOD, and CAT in male Wistar albino rats [47].

The results of the present study showed significant decrease in the level of antioxidant enzymes in pancreas of Cd intoxicated mice which may be due to direct binding of $\mathrm{Cd}$ to the active sites of the enzymes and increased MDA level because of the accumulation of lipid peroxidation substances produced by $\mathrm{Cd}$ intoxication $[48,49]$. On the other side, curcumin supplementation resulted in decrease in lipid peroxidation and showed significant elevation in SOD, CAT, and GPx in pancreatic tissue, indicating the protective effect of curcumin against $\mathrm{Cd}$ toxicity. This work is in agreement with the results of Lyons, and Suryanarayana et al. $[50,51]$ as they reported a significant elevation in concentration of thiobarbituric acid reactive substances (TBARS) in various tissues of Wistar rats such as liver, kidney, heart, pancreas, and RBCs indicating elevated oxidative stress, but they found significant decline in TBARS in the liver, kidney, heart, pancreas, and RBCs of curcumin/turmerictreated groups as compared to untreated diabetic group, showing inhibition of hyperglycemia-induced oxidative stress. Similarly, Aziz reported significant decreased levels of MDA in pancreas, liver, and aorta treated with the novel water-soluble curcumin [52]. Sharma [21] also reported the significant decreased level of MDA in pancreas of Swiss albino mice when exposed to Cd.
Oxidative stress is an important mechanism of Cd toxicity and might alter antioxidant defense system and stimulates the formation of ROS such as hydroxyl radicals and singlet oxygen. $\mathrm{Cd}$ accumulation in pancreas is possibly caused due to its role in detoxification. MT present in pancreas contains a significant amount of cysteine amino acid. Cysteine contains sulfhydryl group that has high affinity toward $\mathrm{Cd}$, thus it could tolerate high Cd concentration [49]. Lipid peroxidation is considered to be a cellular deteriorating process induced by oxidative stress that occurs readily in the tissues rich in highly oxidizable polyunsaturated fatty acids which impairs cell membrane fluidity resulting in alteration in the malfunctioning of membrane-bound enzymes and receptors [53]. Similarly, Sarkar [54] reported that Cd poisoning affects polyunsaturated fatty acids of biofilms, causing lipid peroxidation and membrane damage. Lipid peroxidation is commonly considered as a biomarker of cell oxidative damage. MDA is a secondary product of lipid peroxidation that reflects the degree of ROS attack and can be used to indicate the oxidation of membranes $[55,56]$. The cellular defense system to combat free radicals includes SOD, CAT, and GPx [57]. SOD can instantly convert harmful oxygen free radicals into $\mathrm{H}_{2} \mathrm{O}_{2}$ or peroxide. CAT can transform $\mathrm{H}_{2} \mathrm{O}_{2}$ into $\mathrm{H}_{2} \mathrm{O}$ and $\mathrm{O}_{2}$, while GPx decomposes peroxides such as $\mathrm{H}_{2} \mathrm{O}_{2}$ [58]. Casalino [59] suggested that Cd-induced displacement of $\mathrm{Zn}, \mathrm{Mn}$ from the active sites of SOD, resulting in its decreased activity $[59,60]$.

The antioxidant action of curcumin is attributed to its conjugated structure which includes two methoxylated phenols and an enol form of $\beta$-diketone. The structure is shown to have a distinctive radical trapping capacity as a chain-breaking antioxidant [61]. Dinokova and Talalay [62] also found that curcumin is a bifunctional antioxidant because of its ability to react directly with ROS and to induce an upregulation of various cytoprotective and antioxidant proteins. Treatment of curcumin significantly declined the level of TBARS $\left({ }^{*} \mathrm{p}<0.05\right)$ and increased the activity of GSH and SOD $\left({ }^{*} \mathrm{p}<0.05\right)[63]$. Curcumin has a property to prevent the islets $\beta$-cells damage, decline the insulin resistance and oxidative stress [64]. The administration of curcumin to diabetic rats significantly normalized their blood sugar level, TBARS value, and elevated the activities of antioxidant enzymes such as SOD and GPx [65]. Similar results were obtained in streptozotocin-induced diabetic rats treated with turmeric [66-68]. Further, curcumin was found to be effective in decreasing oxidative damage induced by $\mathrm{Cd}$ which resulted in lower MDA concentration, it was observed to be capable of inhibiting the formation of ROS and induced high antioxidant activity [69-71]. Curcumin protection against Cd-induced oxidative stress was observed by significantly increased GPx activity and decreased MDA concentration in blood of rats [72]. The amelioration by curcumin is observed in diabetic rats with significant improvement in MDA, SOD, and CAT enzymes as compared to untreated group [73]. Similar results were also reported by Lyons, Adhikari et al., Hussein and EL-Maksoud, and Seo et al. [50,64,74,75].

\section{CONCLUSION}

Cd induced oxidative stress in pancreas of albino mice. The results of the present study suggest that administration of curcumin though significantly improves but were not able to completely prevent oxidative stress in Cd-induced toxicity in pancreatic tissue of albino mice. Curcumin at a dose of $100 \mathrm{mg} / \mathrm{kg}$ gives encouraging results by enhancing antioxidant activity and shows a rise in endogenous defense directly by decreasing lipid peroxides in Cd-treated as well as only curcumin-treated mice (+ve control).

\section{ACKNOWLEDGMENT}

The authors gratefully acknowledge the Department of Zoology and Environmental Sciences, Punjabi University, Patiala, for providing the required facilities to pursue the research work.

\section{AUTHORS' CONTRIBUTION}

We declare that this work was done by the authors named in this article. Suman Sharma designed the experiment and edited the manuscript. 
Anu performed the experiment, interpreted the data, and prepared the manuscript.

\section{CONFLICTS OF INTEREST}

The authors declare that they have no conflicts of interest.

\section{REFERENCES}

1. Voldner EC, Alvo M. Estimation of wet deposition of sulfur, nitrogen, cadmium and lead to the Great Leaks. Environ Sci Technol 1993;27:292-8.

2. Bao RK, Zheng SF, Wang XY. Selenium protects against cadmiuminduced kidney apoptosis in chickens by activating the PI3K/AKT/Bcl2 signaling pathway. Environ Sci Pollut Res Int 2017;24:20342-53.

3. Sun B, Xing M. Evaluated the twenty-six elements in the pectoral muscle of as-treated chicken by inductively coupled plasma mass spectrometry. Biol Trace Elem Res 2016;169:359-64.

4. Martin MH, Nriagu JO. Cadmium in the environment. Part 2. Health effects. J Ecol 1998;71:343.

5. Li JT, Qiu JW, Wang XW, Zhong Y, Lan CY, Shu WS, et al. Cadmium contamination in orchard soils and fruit trees and its potential health risk in Guangzhou, China. Environ Pollut 2006;143:159-65.

6. Wang L, Zhou X, Yang D, Wang Z. Effects of lead and/or cadmium on the distribution patterns of some essential trace elements in immature female rats. Human Exp Toxicol 2011;30:1914-23.

7. Uetani M, Kobayashi E, Suwazono Y, Honda R, Nishijo M, Nakagawa $\mathrm{H}$, et al. Tissue cadmium $(\mathrm{Cd})$ concentrations of people living in a cd polluted area, Japan. Biometals 2006;19:521-5.

8. El-Muayed M, Raja MR, Zhang X, MacRenaris KW, Bhatt S, Chen X, et al. Accumulation of cadmium in insulin-producing beta cells. Islets 2012;4:405-16.

9. Patra RC, Swarup D, Senapati SK. Effects of cadmium on lipid peroxides and superoxide dismutase in hepatic, renal and testicular tissue of rats. Vet Hum Toxicol 1999;41:65-7.

10. Chopra M, Rani S, Sharma VL. Evaluating the protective efficacy of combination and Withania somnifera and vitamin E against cadmium induced oxidative stress mediated hepatic histopathology and genotoxicity in murine model. Int J Pharm Pharm Sci 2017;9:230-5.

11. Evans JL, Goldfine ID, Maddux BA, Grodsky GM. Are oxidative stress-activated signaling pathways mediators of insulin resistance and beta-cell dysfunction? Diabetes 2003:52:1-8.

12. Han JC, Park SY, Hah BG, Choi GH, Kim YK, Kwon TH, et al. Cadmium induces impaired glucose tolerance in rat by down-regulating GLUT4 expression in adipocytes. Arch Biochem Biophys 2003;413:213-20.

13. Suzuki KT, Ohnuki R, Yaguchi K, Yamada YK. Accumulation and chemical forms of cadmium and its effect on essential metals in rat spleen and pancreas. J Toxicol Environ Health 1983;11:727-37.

14. Liu J, Qu W, Kadiiska MB. Role of oxidative stress in cadmium toxicity and carcinogenesis. Toxicol Appl Pharmacol 2009;238:209-14.

15. El-Bahr SM. Biochemistry of free radicals and oxidative stress. BMC Complementary Altern Med 2013;1:111-7.

16. MatEs JM, Perez-Gmez C, De Castro IN. Antioxidant enzymes and human diseases. Clin Biochem 1999;32:595-603.

17. Lei LJ, Jin TY, Zhou YF. Insulin expression in rats exposed to cadmium. Biomed Environ Sci 2007;20:295-301.

18. Kunchandy E, Rao MN. Oxygen radical scavenging activity of curcumin. Int J Pharmacol 1990;58:237-40.

19. Sharma OP. Antioxidant activity of curcumin and related compounds. Biochem Pharmacol 1976;25:1811-2.

20. Deng SL, Chen WF, Yang BZ, Liu ZL. Protective effects of curcumin and its analogues against free radical-induced oxidative haemolysis of human red blood cells. Food Chem 2006;98:112-19.

21. Sharma S, Anu KA. Effect of Curcuma longa supplementation on lipid peroxidation, serum amylase, lipase activites in mice exposed to cadmium. Int J Adv Res 2017;5:786-92.

22. Huang MT, Lou YR, Ma W, Newmark HL, Reuhl KR, Conney AH, et al. Inhibitory effects of dietary curcumin on forestomach, duodenal, and colon carcinogenesis in mice. Cancer Res 1994;54:5841-7.

23. Rao CV, Rivenson A, Simi B, Reddy BS. Chemoprevention of colon carcinogenesis by dietary curcumin, a naturally occurring plant phenolic compound. Cancer Res 1995;55:259-66.

24. Baliga MS, Katiyar SK. Chemoprevention of photocarcinogenesis by selected dietary botanicals. Photochem Photobiol Sci 2006;5:243-53.

25. Panday U, Chandra A, Awasthi S, Jin GF, Piper JT, Godley BF, et al. Attenuation of galactose cataract by low levels of dietary curcumin.
Nutr Res 2000;20:515-26.

26. Suryanarayana P, Krishnaswamy K, Reddy GB. Effect of curcumin on galactose-induced cataractogenesis in rats. Mol Vis 2003;9:223-30.

27. Suryanarayana P, Saraswat M, Mrudula T, Krishna TP, Krishnaswamy K, Reddy GB, et al. Curcumin and turmeric delay streptozotocin-induced diabetic cataract in rats. Invest Ophthalmol Vis Sci 2005:46:2092-9.

28. Mukhopadhyay A, Basu N, Ghatak N, Gujral PK. Anti-inflammatory and irritant activities of curcumin analogues in rats. Agents Actions 1982;12:508-15.

29. Kuroda M, Mimaki Y, Nishiyama T, Mae T, Kishida H, Tsukagawa M, et al. Hypoglycemic effects of turmeric (Curcuma longa L. Rhizomes) on genetically diabetic KK-ay mice. Biol Pharm Bull 2005;28:937-9.

30. Sajithlal GB, Chithra P, Chandrakasan G. Effect of curcumin on the advanced glycation and cross-linking of collagen in diabetic rats. Biochem Pharmacol 1998:56:1607-14.

31. Jain SK, Rains J, Jones K. Effect of curcumin on protein glycosylation, lipid peroxidation, and oxygen radical generation in human red blood cells exposed to high glucose levels. Free Radic Biol Med 2006;41:92-6.

32. Nanda A, Gupta N. Efficacy of turmeric on blood glucose and polyol pathway in diabetic albino rats. Plant Foods Hum Nutr 2002;57:41-52.

33. Fujisawa S, Atsumi T, Ishihara M, Kadoma Y. Cytotoxicity reactive oxygen species-generating activity and radical scavenging activity of curcumin and other related compounds. Anti-Cancer Res 2004;24:563-70.

34. Spinas GA. The dual role of nitric oxide in islets $\beta$-cells. News Physiol Sci 1999;14:49-54

35. Pan MH, MLin-Shiiau SY, Lin JK. Comparative studies on the suppression of nitric oxide synthase by curcumin and its hydrogenated metabolites through down-regulation of ikappa bkinase and NFkappaB activation in macrophages. Biochem Pharmacol 2000;60:1665-76.

36. Kalpana C, Menon VP. Curcumin ameliorates oxidative stress during nicotine-induced lung toxicity in wistar rats. Ital $\mathrm{J}$ Biochem 2004;53:82-6

37. Polasa K, Naidu AN, Ravindranath I, Krishnaswamy K. Inhibition of $\mathrm{B}(\mathrm{a}) \mathrm{P}$ induced strand breaks in presence of curcumin. Mutat Res 2004;557:203-13.

38. Kamel R, Hashim AA, Ali SA. Palliative effect of curcumin on stzinduced diabetes in rats. Int J Pharm Pharm Sc 2014;6:558-63.

39. Wilbur KM, Bernheim F, Shapiro OW. The thiobarbituric acid reagent as a test for oxidation of unsaturated fatty acids by various agents. J Biochem Biophys 1949;24:305-13.

40. Das K, Samamta L, Chainy GB. A modified spectrophotometric assay for superoxide dismutase using nitrite formation by superoxide radicals. Indian J Biochem Biophys 2009;2:43-50.

41. Aebi HE. Catalase. In: Bergmeyr HU, editor. Methods of Enzymatic Analysis. Vol. 3. Weinheim: Verlag Chemie; 1983. p. 273-86.

42. Ahrens RA. Glutathione peroxidase: A role for selenium (Rotruck 1972). J Nutr 1997;127:1052S-1053S.

43. Lenzen S, Drinkgern J, Tiedge M. Low antioxidant enzyme gene expression in pancreatic islets compared with various other mouse tissues. Free Radic Biol Med 1996;20:463-6.

44. Patra RC, Rautray AK, Swarup D. Oxidative stress in lead and cadmium toxicity and its amelioration. Vet Med Int 2011;2011:457327.

45. Sargazi M, Zal F, Karbalaei N. Effects of cadmium on oxidative stress markers, and insulin secretion and content in pancreatic isolated islet of rats. J. Mazandaran Univ Med Sci 2018;27:1-14.

46. Liu R, Jia T, Cui Y, Lin H, Li S. The protective effect of selenium on the chicken pancreas against cadmium toxicity via alleviating oxidative stress and autophagy. Biol Trace Elem Res 2017;184:240-6.

47. Palati DJ, Vanapatla SR. Protective role of Aerva monsoniae and selenium on cadmium-induced oxidative liver damage in rats. Asian $\mathbf{J}$ Pharm Clin Res 2018;11:177-81.

48. Waisberg M, Joseph P, Hale B, Beyersmann D. Molecular and cellular mechanisms of cadmium carcinogenesis. Toxicology 2003;192:95-117.

49. Bashir N, Manoharan V, Miltonprabu S. Grape seed proanthocyanidins protects against cadmium induced oxidative pancreatitis in rats by attenuating oxidative stress, inflammation and apoptosis via nrf-2/ HO-1 signaling. J Nutr Biochem 2016;32:128-41.

50. Lyons TJ. Oxidized low-density lipoproteins, a role in the pathogenesis of atherosclerosis in diabetes. Diabet Med 1991;8:411-9.

51. Suryanarayana P, Satyanarayana A, Balakrishna N, Kumar PU, Reddy GB. Effect of turmeric and curcumin on oxidative stress and antioxidant enzymes in streptozotocin-induced diabetic rat. Med Sci Monit 2007;13:BR286-92.

52. Abdel Aziz MT, El-Asmar MF, El-Ibrashy IN, Rezq AM, Al-Malki AL, Wassef MA, et al. Effect of novel water soluble curcumin derivative on experimental Type- 1 diabetes mellitus (short term study). Diabetol 
Metab Syndr 2012;4:30

53. Halliwell B. Lipid peroxidation, antioxidants and cardiovascular disease: How should we move forward? Cardiovasc Res 2000;47:410-8.

54. Sarkar S, Yadav P, Bhatnagar D. Lipid peroxidative damage on cadmium exposure and alterations in antioxidant system in rat erythrocytes: A study with relation to time. Biometals 1998;11:153-7.

55. Jacob RA, Burri RA. Oxidative damage and defence. Am J Clin Nutr 1996;63:985-90.

56. Gutteridge JM. Lipid peroxidation and antioxidants as biomarkers of tissue damage. Clin Chem 1995;41:1819-28.

57. Sevcikova M, Modra H, Slaninova A, Svobodova Z. Metals as a cause of oxidative stress in fish: A review. Vet Med Czech 2011;56:537-46.

58. Yao XH, Chen L, Nyomba BL. Adult rats prenatally exposed to ethanol have increased gluconeogenesis and impaired insulin response of gluconeogenic. Genes J Appl Physiol 2006;100:642-8.

59. Casalino E, Calzaretti G, Sblano C, Landriscina C. Molecular inhibitory mechanisms of antioxidant enzymes in rat liver and kidney by cadmium. Toxicology 2002;179:37-50.

60. Shukla G, Chiu J, Hart BA. Cd induced elevation in the gene expressions of the regulatory subunit of glutamylcysteine synthetase in rat lung and alveolar epithelial cells. Toxicology 2000;151:45-54.

61. Masuda T, Maekawa T, Hidaka K, Bando H, Takeda Y, Yamaguchi H. Chemical studies on antioxidant mechanism of curcumin: Analysis of oxidative coupling products from curcumin and linoleate. J Agric Food Chem 2001;49:2539-47.

62. Dinkova-Kostova AT, Talalay P. Direct and indirect antioxidant properties of inducers of cytoprotective proteins. Molecular Nutr Food Res 2008;52:128-38.

63. Chaudhary B, Agarwal S, Bist R. Curcumin amends oxidative stress and antioxidants status in olfactory lobes, cerebrum, hypothalamushippocampus, cerebellum and pons-medulla of mice acutely intoxicated with lindane. Int J Pharm Pharm Sci 2016;8:244-8.

64. Adhikari R, Jyothi Y, Bora D, Veena V. A combined effect of aqueous extract of Curcuma longa linn. with metformin in diabetes induced neuroptahic pain in rats. Asian J Pharm Clin Res 2015;8:166-70

65. El-Bahr SM, El-Sabagh IM. Hepatic gene expression of insulin like growth factor and selected antioxidants in diabetic rats treated with turmeric or black cumin seed. Br Biotechnol J 2014;4:778-93.

66. Arun N, Nalini N. Efficacy of turmeric on blood glucose and polyol pathway in diabetic albino rats. Plant Foods Hum Nutr 2002;57:41-52.

67. Sharma S, Kulkarni SK, Chopra K. Curcumin, the active principle of turmeric (Curcuma longa), ameliorates diabetic nephropathy I rats. Clin Exp Pharmacol Physiol 2002;33:940-5.

68. Hussein HK, Abu-Zinadah OA. Antioxidant effect of curcumin extracts in induced diabetic wister rats. Int J Zool Res 2010;6:266-76.

69. Venkatesan N, Punithavathi D, Arumugan V. Curcumin prevents adriamycin nephrotoxicity in rats. Br J Pharmacol 2000;12:231-234.

70. Biswas SK, McClure D, Jimenez LA, Megson IL, Rahman I. Curcumin induces glutathione biosynthesis and inhibits NFkappaB activation and interleukin-8 release in alveolar epithelial cells: mechanism of free radical scavenging activity. Antioxid Redox Signal 2005;7:32-41.

71. Reddy AC, Lokesh BR. Studies on the jnhibitory effects of curcumin and eugenol on the formation of reactive oxygen species and the oxidation of ferrous ion. Mol Cell Biochem 1994;137:1-8

72. Attia AM, Ibrahim FA, El-Latif NA, Aziz SW. Antioxidant effects of curcumin against cadmium chloride-induced oxidative stress in the blood of rats. J Pharmacog Phytother 2014;6:33-40

73. Khattab HA, Al-Faleh AA, Al-Amoudi NS. Effect of ginger, curcumin and their mixture on blood glucose and lipids in diabetic rats. Life Sci J 2013;10:428-42.

74. Hussein MA, EL-Maksoud HA. Biochemical effects of resveratrol and curcumin combination on obese diabetic rats. J Mol Clin Pharm $2013 ; 4: 1-10$

75. Seo KI, Myung-Sook C, Ju JU, Kim HJ, Jiyoung Y, Jeon SM, et al. Effect of curcumin supplementation on blood glucose, plasma insulin, and glucose homeostasis related enzyme activities in diabetic $\mathrm{db} / \mathrm{db}$ mice. Mol Nutr Food Res 2008;52:995-1004. 